\title{
A nominalização no português do Brasil*
}

\author{
Luiz Carlos de Assis Rocha \\ Universidade Federal de Minas Gerais
}

\section{Abstract}

The morphological phenomenon of nominalization is a lexical standard which consists of the fomation of abstract substantives from verbs (consagrar/consagração, fingir/fingimento). Based on the principles of Generative Morphology, this article aims to better define the phenomenon, as well as to develop some aspects related to this linguistic mechanism, such as: the question of the derivation of the zero suffix (the problem of regressives), the study of what may be called the iterative -ção suffix and the relation between nominalization and discourse type. 


\section{INTRODUÇÃO}

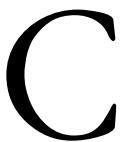

omo objetivo geral, este trabalho pretende demonstrar que o léxico português, sob o ponto de vista de sua estruturação morfológica, constitui um conjunto harmonioso, funcional e sistemático, com tendências, constâncias, ou, mais especificamente, regras - como veremos a seguir -, que fornecem a essa estrutura princípios gerais de organização.

Como objetivo específico, este trabalho pretende descrever o fenômeno morfológico da nominalização em português, com o intuito de demonstrar, através da descrição desse fenômeno, a estruturação morfológica da língua, a que nos referimos no primeiro parágrafo.

A nominalização stricto sensu é um fenômeno morfológico que consiste na formação de nomes a partir de verbos. Em outras palavras, podemos dizer que, dado um verbo, é possível prever a existência de um nome abstrato, derivado, sufixado, correspondente, com o sentido de 'ato, processo, fato, resultado, estado, evento ou modo de X', (Gunzburger, 1979), sendo X o verbo que constitui a base do processo (consagrar/consagração, julgar/julgamento, contar/contagem, etc.).

Para a consecução desses objetivos, estamos nos apoiando em alguns pressupostos teóricos, que passamos a expor na seção seguinte.

\section{PRESSUPOSTOS TEÓRICOS}

As idéias aqui apresentadas tomam como base os princípios gerais da Gramática Gerativa, sem contudo, nos atermos aos formalismos dessa "escola". Há certos conceitos expostos pela chamada "teoria padrão" e pela "hipótese lexicalista", que permanecem 
vivos até hoje, tais como os de gramática subjacente, competência lexical, regras morfológicas, produtividade lexical, etc. Devido à copiosa literatura existente sobre o assunto, não vemos necessidade de desenvolver questões como essas, mas o leitor poderá consultar especialmente Chomsky (1970), Aronoff (1976), Basílio (1980), Scalise (1984), Anderson (1992), Katamba (1993), Villalva (1994) e Rocha (1998). De qualquer forma, é importante realçar a mudança de atitude dos estudiosos no que se refere à passagem da teoria padrão para a hipótese lexicalista, ocasião em que a morfologia deixou de ser "transformacionalista" para ser "lexicalista". Como pano de fundo e, mais do que isso, como fundamento para essa mudança radical dos estudos morfológicos, surgiu o artigo de Chomsky (1970) intitulado Remarks on nominalization. Ao estabelecer distinções sintáticas, semânticas e de estruturação interna entre "gerundive nominals" e "derived nominals", Chomsky, segundo Scalise (1984:19), "conclui que nominais derivados não podem ser criados através de transformações a partir de um verbo na estrutura profunda e propõe, em vez disso, um tratamento lexical para tais verbos, isto é, através de regras morfológicas que operam dentro do componente lexical". Essa revolução coperniana nos estudos lingüísticos vai colocar as regras morfológicas no compo-nente básico do léxico e não mais como resultado de transformações, como propunha a teoria padrão.

Tendo, portanto, como pressuposto uma visão lexicalista da morfologia, pretendemos neste trabalho descrever o fenômeno da nominalização em português com base em algumas propostas teóricas, tais como:

a - A noção de redundância lexical, desenvolvida por Jackendoff (1975). Em sua conhecida Teoria da Entrada Plena, ao criar um modelo com o intuito de explicar as nominalizações e os vários tipos de relações lexicais, Jackendoff estabelece, dentre outras coisas, que em relações do tipo nome/verbo, há duas entradas lexicais independentes, mas relacionadas entre si. O autor estabelece a noção de redundância lexical, segundo a qual, como 
afirma Basílio (1980:32), "uma entrada lexical X tendo tais e tais propriedades é relacionada a uma entra-da lexical W, tendo tais e tais propriedades".

b - A concepção de produtividade lexical, ou seja, de que o falante pode produzir, a todo momento, novos itens lexicais, de acordo com a sua competência lexical. Aronoff (1976) preocupou-se especialmente com essa questão, tendo deixado uma contribuição inestimável para o estudo da produtividade no léxico, ao especificar as condições de funcionamento de uma regra morfológica, de acordo com as características morfológicas da base.

c - A idéia de que, segundo Basílio (1980), a língua apresenta dois tipos de regra morfológica: a RAE (Regra de Análise Estrutural) e a RFP (Regra de Formação de Palavras). A primeira destina-se ao reconhecimento de estruturas morfológicas de palavras já existentes na língua, e a segunda, à formação de novos itens lexicais. A Morfologia Gerativa preocupa-se basicamente com a fixação das RFP's de uma língua.

d - O conceito de padrão lexical, desenvolvido por Basílio (1980), que se caracteriza por um tipo de relacionamento entre determinadas palavras da língua e que se caracteriza pela fixidez e pela previsibi-lidade. Em outros termos: dada uma determinada palavra, é possível prever a existência de outra, desde que satisfeitas tais e tais condições. São exemplos de padrões lexicais, ou, mais especificamente, de padrões sufixais: a formação de nomes a partir de adjetivos (belo/beleza), a formação de agentivos a partir de verbos (descobrir/descobridor) e o fenômeno que estamos analisando, ou seja, a formação de nomes a partir de verbos (consagrar/consagração).

\section{A NOMINALIZAÇÃO}

A nominalização, fenômeno morfológico caracterizado pela formação de nomes a partir de verbos, como vimos, é um exemplo 
típico de padrão lexical, ou seja, do alto grau de regularidade das formações sufixais. Como foi dito anteriormente, dado um verbo, é possível prever a existência de um nome derivado correspondente, com o sentido de 'ato, efeito, processo, fato, resultado, estado, evento ou modo de X'. O produto poderá ser uma forma institucionalizada na língua ou uma formação nova. Eis alguns exemplos:

$\begin{array}{llll}\text { preparar } & \text { preparação } & \text { retornar } & \text { retorno } \\ \text { fingir } & \text { fingimento } & \text { malhar } & \text { malhação } \\ \text { aprender } & \text { aprendizagem } & \text { agitar } & \text { agito } \\ \text { exigir } & \text { exigência } & \text { atingir } & \text { (?)atingimento } \\ \text { abrir } & \text { abertura } & \text { acoplar } & \text { (?)acoplação } \\ \text { subir } & \text { subida } & \text { fujimorizar } & \text { (?)fujimorização }\end{array}$

Desse modo, caracteriza-se o que estamos chamando de nominalização stricto sensu. É interessante observar que o termo nominalização, fora do âmbito da morfologia lexicalista, poderá levar a interpretações ambíguas (Basílio, 1980:89), uma vez que o significado previsível desse item é simplesmente o de 'processo de nominalizar'. Ora, em jogador, fabricante lavatório, por exemplo, deparamos também com nomes formados a partir de verbos. Tratase, portanto, neste caso, de nominalização lato sensu. Neste trabalho, estamos considerando apenas a nominalização stricto sensu.

Ao analisarmos o componente semântico da nominalização, constatamos que o nome formado a partir do verbo refere-se, na maioria das vezes, ao 'ato de X'. Isso nos permitiu fixar um tipo de teste, que tem auxiliado a identificar e a descrever melhor as formas nominalizadas. Esse teste apresenta a seguinte estrutura:

SUJ. + VERBO + COMPLEMENTO (se houver), (mas) esse Y

(sendo $\mathrm{Y}$ a forma nominalizada do verbo ).

Vejamos alguns exemplos:

Luísa tentava preparar um bolo, mas essa preparação seria trabalhosa. 
Maura desejava comprar uma casa. Essa compra iria acarretar muitas dívidas.

André costumava fingir que era rico, mas esse fingimento não enganava ninguém.

A Petrobrás precisa atingir a produção de 1.200 .000 barris de petróleo por dia. Mas esse atingimento só será possível se... Constata-se que as árvores deste bosque morreram. A morte pode ser explicada...

Esse tipo de teste, que pode apresentar pequenas variações, foi de extrema importância para a elaboração deste trabalho, por possibilitar a descoberta ou a constatação de diversas propriedades que caracterizam melhor o fenômeno da nominalização, como veremos nos itens que se seguem. A não-aprovação no teste evidenciará a não-caracterização de um item como nominal, ou seja, como produto da nominalização. Não é o caso de morte, por exemplo, citado na última frase, que pode ser parodiado por 'fato de X', como propõe Gunzburger (1979:41): "O fato de as árvores terem morrido pode ser explicado ..." (cf. c. item seguinte).

\subsection{Componente semântico}

Embora a forma nominalizada possa apresentar significações diversas, tais como, 'ato, efeito, processo, fato, resultado, estado, evento e modo' (Gunzburger, 1979), parece que o significado mais constante é o de 'ato de X'. Doravante, sintetizaremos o componente semântico dessa regra em "ato de X".

\subsection{Extensão de sentido}

Uma forma nominalizada pode apresentar extensões de sentido, ou seja, um mesmo nominal poderá ser usado como 'ato de X' ou com uma significação específica, como nos exemplos: 
O Ministro da Justiça declarou que o Governo estava errado. Mas a sua declaração não foi bem aceita... ('ato de declarar') Esta declaração apresenta inúmeros erros de português. ('documento')

O Ministro expôs com clareza os seus objetivos, embora a sua exposição tivesse apresentado falhas.

A exposição demorou duas horas. ('evento')

Só com muito trabalho será possível uma administração positiva desta firma. ('ato de administrar')

A administração resolveu demitir os culpados. ('coletivização')

A construção do prédio depende de uma verba especial. ('ato de construir')

A construção está na terceira laje. ('concretização')

A forma nominalizada poderá apresentar extensões de sentido generalizadas, tais como as de 'coletivização' (administração, direção, gerência, governo, criação, etc.), 'evento' (exposição, casamento, batizado, jantar, formatura, partida, etc.), 'concretização' (construção, decoração, exposição, balanço, marca, estacionamento, avaliação, pagamento, etc.) ou extensões de sentido idiossincráticas, como no caso de declaração (de amor), estabelecimento (comercial), impressão ('opinião vaga, noção'), escritura ('documento') e balanço ('molejo, gingado'). Há casos em que uma forma nominalizada, como gravação, por exemplo, poderá ser 'ato de gravar', 'evento' ou 'objeto concreto':

A gravação só pôde ser feita por causa da alta qualidade do artista.

Durante a gravação, apareceram vários problemas técnicos. Esta gravação é de 1938. 


\subsection{Bloqueio paradigmático e desbloqueio}

Em se tratando de um padrão sufixal, a forma nominalizada poderá, como sabemos, apresentar sufixos variados (-mento, -ção, -agem, -ncia, -da, -ura, zero, etc.). Sobre essa diversidade de sufixos falaremos mais adiante. Convém, porém, ressaltar que a existência de determinado nominal em princípio bloqueia o surgimento de possíveis formas concorrentes. É por isso que a língua não apresenta (?)consagramento, por exemplo, porque a consagração já está cristalizada na língua. Mas esse fenômeno, conhecido na literatura como bloqueio paradigmático - uma vez que se obedece a paradigmas diferentes (Rocha, 1998) - não é "geral e irrestrito". A língua apresenta quatro tipos de desbloqueio:

\subsubsection{Desbloqueio rotulativo}

A par de nominais previsíveis sob o ponto de vista semântico, a língua pode apresentar nominais específicos de profissões, ocupações ou de situações especiais. Surgem, portanto, "rotulações" especiais de atos, processos ou estados, como:

$\begin{array}{ll}\text { ligação } & \begin{array}{l}\text { ligamento (termo médico) } \\ \text { ligadura (termo médico) }\end{array} \\ \text { batida } & \text { batimento (termo médico) } \\ \text { caída } & \text { caimento (termo da costura) } \\ \text { salvamento } & \text { salvação (no sentido espiritual) } \\ \text { aparecimento } & \text { aparição (no sentido espiritual) }\end{array}$

Estamos considerando que ligamento, por exemplo, bloqueado a princípio por ligação, é um caso de desbloqueio, se levarmos em conta o que se pode chamar de "semântica de primeiro grau" das formações nominalizadas, que é, em resumo, o 'ato de X'. Em tese, ligação deveria bloquear ligamento, pois ambos significam "ato de X". O desbloqueio se deve, no que se refere à caracterização da regra, à "semântica de segundo grau" desenvolvida pela forma concorrente (ligamento). 


\subsubsection{Desbloqueio cumulativo}

O mecanismo morfológico da nominalização prevê também que determinados produtos, com tais e tais características, além de serem 'atos de X', podem apresentar também, sistematicamente, um outro componente semântico (semântica de segundo grau). Nos exemplos que se seguem, extraídos da linguagem coloquial, o nominal é também iterativo. Ipso facto, o sufixo -ção será nominalizador iterativo (cf. c. seção 10):

$\begin{array}{ll}\text { batida } & \text { bateção } \\ \text { chamada } & \text { chamação } \\ \text { abertura } & \text { abrição } \\ \text { estudo } & \text { estudação } \\ \text { mudança } & \text { mudação }\end{array}$

\subsubsection{Desbloqueio estilístico}

Uma formação nominalizada pode ser desbloqueada por razões estilísticas, ou seja, o falante pode pretender que a formação nova seja mais expressiva, como se deduz dos contextos abaixo:

Vou dar um chego na minha casa. (em vez de chegada) O ladrão deu uma limpa no escritório. (em vez de limpeza) Amanhã vai ter um agito na Praça do Papa. (em vez de agitação)

Você precisa sair desse sufoco. (em vez de sufocamento ou sufocação)

Mamãe vaite darum xingo daqueles. (emvez de xingamento)

Em se tratando de uma função "estilística", é natural que esse tipo de desbloqueio seja comum nas obras literárias. É o que se dá nestas passagens de Guimarães Rosa:

"Muitos homens resmungaram em aprôvo, ali rodeando."

(Rosa, 1967:65) (por aprovação) 
"Tenho a honra de resumir circunstância desta decisão, sem admitir apêlo nem revôgo..." (Rosa, 1967:60) (por revogação) “...não duvidou em lhe deferir hospedamento..." (Rosa, 1972: 100) (por hospedagem)

"A cidade - catastrapes! Que acolhenças?" (Rosa, 1972:165) (por acolbimento)

\subsubsection{Desbloqueio esporádico}

Na fala espontânea, o produto consagrado de uma regra de nominalização pode ser substituído por outro, com base em uma regra concorrente. Isso é feito de maneira esporádica, ou seja, há uma espécie de "escorregadela", em que o falante troca o sufixo acidentalmente. Esse "descuido" se dá em conseqüência da coerção exercida pelo padrão lexical, [ [ V ] suf. ] N, que é muito forte na língua e que é operacionalizado por meio de vários sufixos, como -ação, -mento, -zero, -agem, -ura, etc. É o caso, por exemplo, de acoplação (por acoplamento), contemplação (por contemplação), degeneração (por degeneração), aceleramento (por aceleração), delineamento (por delineação), destinamento (por destinação), gravamento (por gravação), atrasamento (por atraso), transportamento (por transporte), etc.

\subsection{Nominais heterônimos}

Certos verbos podem apresentar, em contextos específicos, o nominal correspondente através de formas heterônimas. Neste caso, não se pode falar, portanto, em mecanismo morfológico de derivação, mas de supletivismo, que se dá com base nos recursos léxicos da língua. Observem-se os seguintes exemplos:

Precisamos terminar com as enormes filas dos bancos. Mas o fim das filas só será possível, se ... (terminar/fim)

Foi necessário aguardar duas horas na fila, mas essa espera foi muito boa, porque o médico... (aguardar/espera) 
As duas irmãs se parecem muito, mas a semelhança é apenas física. (parecer/semelhança)

Todos aqui precisam de carinho, mas essa necessidade está relacionada a fatores psicológicos. (precisar/necessidade)

Todos eles querem progredir, mas essa vontade depende de fatores... (querer/vontade)

\section{VERBOS SEM CONTRAPARTE NOMINAL}

Apesar de se constituir em um dos mais regulares padrões lexicais da língua, há casos em que a contraparte nominal inexiste. É possível enumerar algumas classes de verbos em que isso acontece.

\subsection{Verbos usados na linguagem coloquial}

Como o emprego de formas nominalizadas é mais característico de discursos formais, certos verbos da linguagem coloquial, como, botar, enxergar, cutucar, cavar, não apresentam o nominal correspondente.

Por outro lado, verbos característicos do discurso formal poderão não apresentar a contraparte nominal. Isso se explica, em parte, pelo receio que têm os usuários habituais da norma culta de romper com os padrões estabelecidos. É por isso que diante de verbos como, brandir, pairar, despontar, perdurar, ressaltar, etc. (que, historicamente, não apresentam a forma nominalizada correspondente), o falante culto deixa de produzir a respectiva forma nominalizada, com medo de romper com a língua padrão.

\subsection{Verbos de ligação, auxiliares e indicadores de aspecto}

Verbos como, ser, estar, ficar, parecer e tornar-se (de ligação), ter, haver, ser e estar (auxiliares), e alguns verbos que indicam aspecto, como achar (no sentido de 'encontrar' - aspecto perfectivo pontual), acabar (aspecto terminativo) e completar (aspecto terminativo), não apresentam a forma nominalizada correspondente (cf. c. Basílio, 1980:82). 
Como veremos em 5.4, acabamento não é o nominal correspondente a acabar, pois se trata de um caso de lexicalização semântica. Achamento e completamento, apesar de dicionarizados, não pertencem ao léxico mental (Rocha, 1998:61) do autor deste artigo. Trata-se, portanto, no caso das duas últimas, de palavras possíveis, mas não reais - para usarmos a terminologia empregada por Aronoff (1976:18).

\subsection{Inércia morfológica}

É preciso considerar também que algumas formas derivadas não existem na língua por causa da inércia morfológica (Rocha, 1998:83). Às vezes, uma forma é perfeitamente possível em uma língua, ou seja, não se detecta qualquer tipo de restrição à sua existência, mas, por uma questão de imobilismo lingüístico, ela não apresenta existência real. É o caso, por exemplo, de atingimento, no contexto abaixo, para cuja criação não se pode apontar qualquer tipo de restrição:

O Brasil precisa atingir a produção de 1.200 .000 barris de petróleo por dia. Para atingir essa marca, precisamos trabalhar muito. Mas esse atingimento só será possível, se houver condições...

É possível pensar-se em inércia morfológica no caso de possíveis formas nominalizadas relativas a levar, evitar, segurar, trazer, etc.

\section{NOMINALIZAÇÃO E LEXICALIZAÇÃO}

Antes de examinarmos especificamente cada um dos sufixos nominalizadores, o que vale dizer, cada uma das RFP's (já que cada sufixo caracteriza uma Regra), trataremos da questão da Lexicalização, um fenômeno muito comum entre formas nominalizadas já institucionalizadas. 
Muitas vezes, na aplicação da RAE a uma formação cristalizada do português, deparamos com alguma irregularidade ou desvio da regra quanto aos aspectos fonológico, morfológico, sintático ou semântico. A essa irregularidade ou idiossincrasia dá-se o nome de lexicalização (Bauer, 1983:42-61, Scalise, 1984:25, Rocha, 1998:50). Em outras palavras, uma formação complexa lexicalizada teria uma forma diferente da que apresenta, se ela fosse um produto regular de uma RFP. Tomemos como exemplo o nominal absolvição. Por ser uma forma institucionalizada, devemos aplicar a ela uma RAE e não, uma RFP. A RAE dessa formação é, portanto, [ [absolver] V ] -ção] S. Não se observa qualquer anormalidade na aplicação da RAE; a queda do $r$ e a transformação da vogal temática - $e$ - em - $i$ - são mudanças fonomorfológicas previsíveis. Observe-se agora o caso do verbo absorver, por sinal, uma forma parônima de absolver. O nominal relativo a absorver é absorção, tendo havido a queda de uma sílaba inteira. Caso fosse aplicada a esse verbo a RFP, a forma previsível, portanto, regular, seria (?)absorvição. Esse é um caso típico de lexicalização.

A nominalização lexicalizada pode ser de quatro tipos: prosódica, estrutural, rizomórfica e semântica (cf. c. Rocha, 1998:50).

\subsection{Lexicalização prosódica}

Observem-se os seguintes casos de lexicalização prosódica (cf. c. Bauer, 1983:50):

$\begin{array}{lll}\text { estimular } & \text { estímulo } & \text { em vez de (?)estimulo } \\ \text { retificar } & \text { retífica } & \text { em vez de (?)retifica } \\ \text { criticar } & \text { crítica } & \text { em vez de (?)critica } \\ \text { duvidar } & \text { dúvida } & \text { em vez de (?)duvida } \\ \text { incomodar } & \text { incômodo } & \text { em vez de (?)incomodo } \\ \text { analisar } & \text { análise } & \text { em vez de (?)analise } \\ \text { depositar } & \text { depósito } & \text { em vez de (?)deposito }\end{array}$


Nesses casos o acento tônico recua duas sílabas em vez de uma, como seria de se esperar nas chamadas derivações regressivas deverbais (abandono, contorno, conversa, controle, etc.).

\subsection{Lexicalização estrutural}

Na lexicalização estrutural, observa-se alguma anomalia na estru-tura mórfica da formação nominalizada, como nos exemplos:

$\begin{array}{lll}\text { aborver } & \text { absorção } & \text { em vez de (?)absorvição } \\ \text { afligir } & \text { aflição } & \text { em vez de (?)afligição } \\ \text { adotar } & \text { adoção } & \text { em vez de (?)adotação } \\ \text { compreender } & \text { compreensão } & \text { em vez de (?)compreendição } \\ \text { confessar } & \text { confissão } & \text { em vez de (?)confessação } \\ \text { decidir } & \text { decisão } & \text { em vez de (?)decidição }\end{array}$

Nos casos acima, observa-se que sillabas inteiras são suprimidas. Esse fenômeno, considerado por alguns estudiosos como regra de truncamento (Aronoff, 1976:88), não pode, na verdade, ser considerado como regra, dado o seu caráter idiossincrático. De fato, por que o nominal correspondente a adotaré adoção e o correspondente a anotaré anotação?

\subsection{Lexicalização rizomórfica}

$\mathrm{Na}$ lexicalização rizomórfica, observa-se alguma anomalia na raiz da formação nominalizada, como nos exemplos:

$\begin{array}{llll}\text { abrir } & \text { abertura } & \text { herdar } & \text { herança } \\ \text { agir } & \text { ação } & \text { possuir } & \text { posse } \\ \text { conseguir } & \text { consecução } & \text { prometer } & \text { promessa } \\ \text { convencer } & \text { convicção } & \text { sugerir } & \text { sugestão } \\ \text { decair } & \text { decadência } & \text { surpreender } & \text { surpresa } \\ \text { defender } & \text { defesa } & \text { vencer } & \text { vitória } \\ \text { doer } & \text { dor } & \text { ver } & \text { visão } \\ \text { exceder } & \text { excesso } & & \end{array}$




\subsection{Lexicalização semântica}

Na lexicalização semântica, a formação nominalizada adquire um sentido imprevisível. Em 3.2, vimos que uma forma nominalizada pode apresentar extensões de sentido, ou seja, um mesmo nominal poderá ser usado como 'ato de X' ou com uma significação específica, como nos exemplos:

O Ministro da Justiça declarou que o Governo estava errado. Mas a sua declaração não foi bem aceita ... ('ato de declarar') Esta declaração apresenta inúmeros erros de português. ('documento')

O Ministro expôs com clareza os seus objetivos, embora a sua exposição tivesse apresentado falhas. ('ato de expor') A exposição demorou duas horas. ('evento')

Só com muito trabalho será possível uma administração positiva desta firma. ('ato de administrar')

A administração resolveu demitir os culpados. ('coletivização')

A construção do prédio depende de uma verba especial. ('ato de construir')

A construção está na terceira laje. ('concretização')

Observe-se que nos exemplos de extensão de sentido, como nos acima arrolados, existe uma relação semântica entre os casos considerados previsíveis e os considerados imprevisíveis (declaração/ declaração, etc.). Desse modo, duas ou mais aplicações da mesma palavra convivem na língua, caracterizando-se assim o que se chama de linguagem polissêmica.

Na lexicalização semântica, não existe a convivência de duas formas polissêmicas, mas apenas uma delas, aquela que apresenta um sentido imprevisível. Observe-se a não-existência na língua da forma considerada previsível e a existência das formações lexicalizadas: 
(?) O material de construção vai acabar em dois dias. Mas o acabamento do material não quer dizer que a obra vá parar.

Este vestido apresenta um acabamento de primeira qualidade.

(?) Você precisa segurar a bandeja com as duas mãos. Mas essa segurança tem que ser feita com elegância.

Os seguranças permaneceram calados o tempo todo.

(?) - Vamos desmanchar os erros cometidos na redação. Mas esse desmanche tem que ser feito com cuidado, para não estragar a folha.

O desmanche do carro se deu em duas horas.

É preciso, portanto, não confundir os casos de extensão de sentido (declaração/declaração - cf. c. 3.2), com os de lexicalização semântica (acabar/acabamento). Por outro lado, existem na língua exemplos de falsas nominalizações. É o que se dá, por exemplo, com procuração, que não é, evidentemente, o 'ato de procurar', mas um instrumento jurídico, que não tem nada a ver com a ação de procurar, como se constata pelo exemplo:

(?) Precisamos ajudar a Luísa a procurar o brinco que ela perdeu durante a aula. Mas essa procuração só poderá ser feita no final da aula.

A base de procuração não é, portanto, procurar. Procura- é uma base presa (cf. c. Rocha, 1998), já que é recorrente (cf. c. procurador, por exemplo), mas não se apresenta como uma forma livre, ou seja, como uma palavra da língua portuguesa. Procuração não pertence, portanto, à mesma família, ou ao mesmo grupo lexical de procurar e procura. Um outro exemplo de falsa nominalização é segurança, que não é o nominal correspondente de segurar, como se depreende do contexto:

(?) Segure o meu braço para atravessar a avenida. Mas essa segurança termina quando chegarmos do outro lado. 
Voltando à questão da lexicalização, analisada linhas acima, alguns dos nominais lexicalizados que estamos apresentando são, sob o ponto de vista diacrônico, continuação de formas herdadas do latim: afligir (de affligere) e aflição (de afflictione), adotar (de adoptare) e adoção (de adoptione), agredir (de *aggredire) e agressão (de aggressione), e assim por diante. É preciso deixar claro, no entanto, que tais observações, de natureza diacrônica, escapam à competência lexical do falante comum, como já dissemos anteriormente. Para o lingüista comprometido com a explicitação da gramática subjacente do usuário da língua, tais explicações são dispensáveis, porque $\boldsymbol{n a ̃ o}$ são fornecidas pela competência lingüística do falante. Como sabemos, as análises lingüísticas comprometidas com a interpretação gerativa não podem misturar dados pertencentes a regiões geográficas diferentes (dados diatópicos), a camadas sociais diferentes (dados diastráticos) ou a fatias temporais diferentes (dados diacrônicos). É evidente que relações estruturais que vigoraram no latim há 2.000 anos não são as mesmas relações que vigoram no português atual. A relação affligere/afflictione deve ser explicitada na base nos dados do latim. Dizer que a formação nominal de afligir é aflição, "porque" em latim era afflictione é uma justificativa que não se apóia nos dados fornecidos pela gramática do falante. À morfologia gerativa cabe apenas constatar essas idiossincrasias e atribuí-las a fatores históricos, sem, contudo, tentar explicá-las. Se fizemos uma rápida incursão à diacronia, foi apenas para lembrar a "fundamental importância de se distinguir as formas já feitas dos processos de formação" (Basílio, 1987:25). Foi também para ratificar o ponto de vista, que vimos adotando em nossos trabalhos, expresso através destas palavras de Bauer (1983:292): "A única maneira realística de se obter uma compreensão adequada de como funciona a formação de palavras é ignorando-se as formas lexicalizadas e concentrando-se nos processos produtivos." A rigor, a morfologia gerativa não deveria se preocupar com essas "relíquias morfológicas", para usarmos uma expressão de Aronoff (1976:84), pois, como sabemos, as palavras, uma vez criadas, se cristalizam, podendo adquirir formas e/ou significados imprevisíveis, como vimos com os 
casos de extensão de sentido e de lexicalização. Itens lexicais cristalizados só são interessantes para a morfologia, se as relações paradigmáticas consagradas servem de modelo para a criação de itens novos, como treinar/treinador, jogar/jogador, paquerar/ paquerador, et alii, que poderão servir de modelo para a produção de formas possíveis, como, (?) apelidador, (?)conseguidor, (?)encerrador, (?)estruturador, etc.

Paralelamente à constatação de que uma forma lingüística apresenta lexicalização estrutural, dá-se também na língua o fenômeno da recuperação morfológica (Rocha, 1998). Esse fenômeno consiste no seguinte: consideremos o caso da palavra expulsão, que sofre um truncamento silábico ao se aplicar a ela a RAE correspondente. Em vez de expulsação, tem-se expulsão. É possível, no entanto, na linguagem coloquial, deparar-se com a forma expulsação, como no exemplo: "Esse colégio está virando uma bagunça danada; todo dia é essa expulsação de aluno”. Como se observa, dá-se a recuperação morfológica da RAE, [ [ expulsar ] V -ção ] S. Sob o ponto de vista semântico, o produto, além de significar "ato de X", adquire também uma significação cumulativa de 'ação repetida'. Acrescente-se a isso o fato de a palavra expulsação ser usada apenas na linguagem coloquial. Esta questão será discutida com mais profundidade na seção 10 deste trabalho. Seguem-se outros exemplos de recuperação morfológica: O governo precisa parar com essa concedeção de medalha. (por concessão)

O padre não tem sossego. Fica essa confessação o dia inteiro. (por confissão)

Houve uma discutição danada, durante a noite toda. (por discussão)

O candidato precisa parar com essa prometeção, senão ele vai se dar mal. (por promessa)

Até que enfim, o diretor parou com a suspendeção de alunos. (por suspensão)

Você precisa parar com essa viajação o mês inteiro! (por viagem) 


\section{SUFIXOS NOMINALIZADORES}

Nesta seção analisaremos as principais características dos vários sufixos nominalizadores. Na seção 9 faremos um estudo comparativo da produtividade dos sufixos -ção, zero e -mento.

\subsection{Sufixo -ção}

O sufixo nominalizador -ção é um dos mais produtivos do sistema lingüístico português, além de apresentar inúmeras formações já cristalizadas na língua. Estamos tomando a palavra produtivo no sentido normal, dicionarizado, de que produz, que é capaz de produzir. Assim, o sufixo -ção é produtivo, porque é usado na formação de inúmeras palavras novas na língua. Não estamos, portanto, neste trabalho (apenas como tentativa de simplificação), adotando a posição de Basílio (1996), com relação ao que ela denomina de condições de produtividade de uma RFP (embora concordemos com ela em outros trabalhos). Além disso, rigorosamente falando, sabemos que não é o sufixo que é produtivo ou improdutivo, mas a regra. Estamos simplificando o problema, para não estendermos o trabalho em demasia. Para maiores informações, consulte-se especialmente Basílio (1996) e Rocha (1998).

As formações cristalizadas em -ção podem ser regulares (anotar/anotação, consagrar/consagração) ou lexicalizadas (adotar) adoção, afligir/aflição), como vimos na seção anterior. Neste trabalho, estamos considerando como variante de -ção o sufixo -ão, que aparece em formações do tipo: confusão, persuasão, exaustão, sugestão, união, comunhão, confissão, impressão, etc.

Pode-se apontar inúmeros exemplos de nominais, recentemente criados na língua, formados através da RFP: V $\Rightarrow$ [ [V] -ção] N: desfavelização, fujimorização, mexicanização, argentinização, sarneyzação, terceirização, magicização, absolutização, encucação, robotização, badalação, etc.

Para se ter idéia da presença das formações em -ção na nominalização em português, podemos constatar que da lista de 443 verbos citados por Basílio em Estruturas lexicais do Português, 168, 
ou seja, 37,9\%, apresentam o sufixo -ção. Doravante, todas as referências a essa lista remetem-nos a Basílio (1980:115-126).

\subsection{Sufixo -mento}

Também o sufixo -mento é bastante produtivo no sistema lingüístico português, além de apresentar diversas formações já institucionalizadas. Mas existe uma particularidade interessante com relação a este sufixo: as formas nominalizadas com base na regra [ [ V ] -mento] N são regulares, ou seja, previsíveis, não apresentando a língua casos de lexicalização estrutural com esse sufixo.

Observe-se a relação paradigmática abaixo:

$\begin{array}{ll}\text { acompanhar } & \text { acompanhamento } \\ \text { afastar } & \text { afastamento } \\ \text { aprofundar } & \text { aprofundamento } \\ \text { acolher } & \text { acolhimento } \\ \text { atender } & \text { atendimento } \\ \text { sofrer } & \text { sofrimento } \\ \text { descobrir } & \text { descobrimento } \\ \text { entupir } & \text { entupimento } \\ \text { prosseguir } & \text { prosseguimento }\end{array}$

Na segunda conjugação, a vogal temática do nominal apresenta a forma - $i$-, que é uma transformação da vogal temática -e-, característica da segunda conjugação. Dá-se, portanto, o fenômeno da neutralização, em que as vogais temáticas da segunda e da terceira conjugações se tornam iguais.

Além das formas cristalizadas, a língua apresenta inúmeras formações novas, como: acionamento, afoitamento, agenciamento, aguçamento, apeamento, atrelamento, debilitamento, desfavelamento, despistamento, enfrentamento, fustigamento, metralbamento, prevalecimento, vivenciamento, jateamento, lecionamento, ocupamento, etc. Essas formações, com exceção das três últimas, foram extraídas de Sandmann (1988:53). 
Destacamos apenas alguns casos com o sufixo -mento. Mais exem-plos serão retomados quanto estabelecermos um estudo comparativo entre as formações com os sufixos -ção, zero e -mento (cf. c. seção 9).

Os nominais em -mento representam 13,0 \% da lista de Basílio (58 casos).

\subsection{Sufixo -da/-do}

A língua apresenta inúmeras formações cristalizadas com o sufixo -da, tais como: batida, chegada, despedida, medida, mexida, parada, partida, saída, subida, etc. Neste trabalho estamos considerando o sufixo -do (chamado, pedido, desmentido, etc.) como alomorfe de $-d a$.

Este sufixo nominalizador é altamente produtivo, particularmente na linguagem coloquial. A formação desses nomes designativos de ação apresenta uma particularidade: são empregados em sintagmas juntamente com o verbo dar-dar uma olhada, dar uma esnobada, dar uma estudada, dar uma esticada, dar uma viajada, dar uma descansada, entre diversos outros. Notamos assim que a linguagem coloquial, de extrema importância na evolução e transformação da língua é também uma das principais responsáveis pela formação de novas palavras e, no âmbito específico deste trabalho, de novas formas nominalizadas.

Um nominal em - da poderá aparecer em um contexto que não o apresentado acima (dar uma...):

Apenas com uma olhada a pessoa pode adivinhar ...

Uma esticada a Diamantina, no mês de julho, poderá ser um programa...

14 nominais, ou seja, 3,1\% dos casos apresentam o sufixo -do/ - da na lista de Basílio. 


\subsection{Sufixo-agem}

Este sufixo nominalizador confirma satisfatoriamente a predominância do sentido 'ato de X' para as formas nominalizadas, uma vez que as formas básicas para essas formações são verbos de ação. Isso é evidenciado por Basílio (1984:96): "o sufixo -agem só forma nomes deverbais a partir de verbos de ação". No artigo citado de Basílio - Relevância do fator semântico na descrição de processos de formação de palavras: um estudo das formas X-agem em Português - dentre as 230 formações analisadas, apenas algumas deixam de corresponder unicamente a verbos de ação.

Basílio ainda afirma que a grande maioria das formações em -agem corresponde a "verbos que se referem basicamente a uma ação efetuada por um agente sobre um objeto específico". A autora separa as formações em quatro grupos:

Grupo a - Formações derivadas de verbos com o sentido de "pôr X em Y", em que X é a base nominal e Y indica o local onde a ação é praticada:

$\begin{array}{lll}\text { Base nominal } & \text { Verbo } & \text { Nominal } \\ \text { esmalte } & \text { esmaltar } & \text { esmaltagem } \\ \text { zinco } & \text { zincar } & \text { zincagem } \\ \text { ladrilho } & \text { ladrilhar } & \text { ladrilhagem } \\ \text { asfalto } & \text { asfaltar } & \text { asfaltagem }\end{array}$

Grupo b - Casos em que a base nominal do verbo corresponde ao instrumento utilizado para efetuar uma ação:

$\begin{array}{lll}\text { carimbo } & \text { carimbar } & \text { carimbagem } \\ \text { cinzel } & \text { cinzelar } & \text { cinzelagem } \\ \text { martelo } & \text { martelar } & \text { martelagem }\end{array}$

Grupo c - Casos em que a operação é mais formal do que física:
matriz
matrizagem
moldar moldagem
modelar modelagem 
Grupo d - Casos de locação:

armazenar armazenagem

(?) alfandegar alfandegagem

Além desses tipos, há casos difíceis de subclassificar, como: pilhar pilhagem

sabotar

sabotagem

linchar

(?) linchagem

$\mathrm{Na}$ listagem de Basílio, as formas nominalizadas com -agem comparecem com 8 casos, ou seja 1,8\%.

\subsection{Sufixo -ncia/-nça}

Apesar de apresentar diversas formas nominalizadas (não tão numerosas quanto as formações em -ção, zero $e$-mento), não se pode dizer que este sufixo seja altamente produtivo. Seguem-se exemplos de formações já institucionalizadas na língua:

$\begin{array}{llll}\text { alternar } & \text { alternância } & \text { incumbir } & \text { incumbência } \\ \text { conviver } & \text { convivência } & \text { insistir } & \text { insistência } \\ \text { convir } & \text { conveniência } & \text { ocorrer } & \text { ocorrência } \\ \text { decair } & \text { decadência } & \text { permanecer } & \text { permanência } \\ \text { desistir } & \text { desistência } & \text { preferir } & \text { preferência } \\ \text { exigir } & \text { exigência } & \text { presidir } & \text { presidência } \\ \text { existir } & \text { existência } & \text { resistir } & \text { resistência } \\ \text { falir } & \text { falência } & \text { sobreviver } & \text { sobrevivência } \\ \text { gerir } & \text { gerência } & \text { tolerar } & \text { tolerância }\end{array}$

A forma -nça, alomorfe de -ncia, apresenta-se em alguns poucos nominais cristalizados, como nos exemplos:

confiar

crer

diferir

herdar confiança

crença

diferença

herança lembrar

liderar

mudar

poupar lembrança

liderança

mudança

poupança 
Um exemplo de formação nova com esse sufixo é frevança, que é a prática da ação de frevar ('dançar o frevo'), como neste exemplo citado por Alves (1990:31):

"... esperavam desde a noite da segunda-feira o momento de cair na frevança ..."

Observem-se estes exemplos literários, extraídos da obra de Guimarães Rosa:

"A cidade - catastrapes! Que acolhenças!" (Rosa, 1972:165)

"...uns cinqüenta ou cem homens, repartidos em miúdos grupos, caçando jeito de safança..." (Rosa, 1967:231)

Além das formações esporádicas citadas, é possível apontar alguns exemplos de formações recentes da língua, como: querência, acontecência, aconchegância, etc. Mas trata-se, na verdade, de um sufixo de baixa produtividade, apesar de apresentar várias formações já lexicalizadas.

$\mathrm{Na}$ lista de Basílio, aparecem 27 casos de formações em -ncial -nça, ou seja, 11,9\%.

\subsection{Sufixo -ura / -tura/ -dura}

Este é um sufixo que apresenta poucas formas nominalizadas, e estas possuem, em grande parte dos casos, empregos que extrapolam o sentido de 'ato de X', como vimos na seção 3:

$\begin{array}{llll}\text { abrir } & \text { abertura } & \text { ler } & \text { leitura } \\ \text { assinar } & \text { assinatura } & \text { escrever } & \text { escritura } \\ \text { candidatar-se } & \text { candidatura } & \text { laquear } & \text { laqueadura } \\ \text { formar-se } & \text { formatura } & \text { romper } & \text { ruptura }\end{array}$

Na lista de Basílio, os nominais em -ura equivalem a 1,3\% dos casos, com 6 exemplos. 


\subsection{Sufixo -ia}

Trata-se de um sufixo nominalizador pouco produtivo, como se constata pelas formações abaixo. Na lista de Basílio aparece com 2 exemplos, ou seja, 0,4\% dos casos:

$\begin{array}{ll}\text { aposentar-se } & \text { aposentadoria } \\ \text { garantir } & \text { garantia }\end{array}$

Além dos exemplos de Basílio, a língua apresenta outros nominais em -ia, como, melhoria e enxertia.

\subsection{Sufixo -mo}

A língua apresenta alguns poucos exemplos de nominais derivados com o sufixo $-m o$, como em

$\begin{array}{ll}\text { acrescentar } & \text { acréscimo } \\ \text { emprestar } & \text { empréstimo } \\ \text { decrescer } & \text { decréscimo. }\end{array}$

$\mathrm{Na}$ lista de Basílio, aparece apenas 1 exemplo (acréscimo) com o sufixo - mo, ou seja, 0,2\% dos casos. Trata-se de um sufixo improdutivo em português.

\section{DERIVAÇÃO SUFIXAL ZERO}

$\mathrm{O}$ padrão lexical $\mathrm{V} \Rightarrow \mathrm{N}$ abstr. apresenta algumas formações que têm merecido um tratamento especial por parte dos estudiosos (Basílio: s.d., Gamarski:1984, Villalva: 1987, Rocha:1998). São os chamados regressivos, dos quais apresentamos alguns exemplos:

$\begin{array}{llll}\text { abandonar } & \text { abandono } & \text { enfeitar } & \text { enfeite } \\ \text { descansar } & \text { descanso } & \text { tocar } & \text { toque } \\ \text { gritar } & \text { grito } & \text { agitar } & \text { agito } \\ \text { esperar } & \text { espera } & \text { xingar } & \text { xingo } \\ \text { censurar } & \text { censura } & \text { sufocar } & \text { sufoco }\end{array}$


Tem-se discutido muito a respeito da direcionalidade do processo dessas formações. Não vamos apresentar aqui as diversas posições em torno do assunto, pois isso seria fugir ao escopo deste trabalho. Vamos apenas colocar alguns argumentos que nos levam a enquadrar os exemplos citados acima no processo de nominalização com sufixo zero, ou seja, vamos defender o ponto de vista de que tais construções são formadas a partir de verbos.

Em primeiro lugar, é preciso considerar que na nominalização, a direcionalidade do processo é clara, como vimos no início deste trabalho. Dado um verbo, é possível prever a existência de um substantivo abstrato, derivado, sufixado, correspondente, com o sentido de 'ato, efeito, fato, estado, processo, evento, modo ou resultado de X', sendo X o verbo que constitui a base do processo (consagrar/consagração, julgar/julgamento, contar/contagem, etc.). Observe-se que a presença do sufixo caracteriza a derivação. Contagem é derivado de contare não, o inverso. A existência desse padrão geral vai nos levar à conclusão de que existe uma coerção do sistema lingüístico no sentido de se formarem nomes abstratos a partir de verbos. A partir daí, pode-se concluir que, via de regra, nomes abstratos fonologicamente e semanticamente relacionados a verbos são deles derivados. Como afirma Basílio (1980: 83), "nomes podem constituir a base para a formação de verbos, mas verbos devem ter uma contraparte nominal no léxico" (grifos da autora).

Em segundo lugar, observe-se que na língua coloquial, a direcionalidade do processo torna-se evidente, uma vez que é possível flagrar o surgimento do novo vocábulo. Observem-se estes exemplos da língua falada:

Vou dar um chego na minha casa.

O ladrão fez uma limpa no escritório.

Amanhã vai ter um agito na Praça do Papa.

Você precisa sair desse sufoco.

Mamãe vai te dar um xingo daqueles! 
Trata-se de criações recentes da língua. Intuitivamente, os falantes dirão que chego, limpa, agito, sufoco exingo vêm de chegar, limpar, agitar, sufocar e xingar, e não, o contrário. Além disso, como se sabe, essas novas formações não são dicionarizadas, o que vem comprovar o nosso ponto de vista.

Finalmente, é possível considerar, sob o ponto de vista estritamente morfológico, que as chamadas formações regressivas são portadoras de sufixo zero.

A concepção de sufixo zero é antiga em Lingüística e fez fortuna no Estruturalismo. Embora o Estruturalismo, como corrente lingüística, tenha esbarrado em problemas insolúveis, há certos conceitos que permanecem vivos e mesmo indispensáveis até hoje, como o de sufixo zero. Sem nos atermos aos formalismos e aos rigores da Lingüística Estrutural, diríamos apenas que é possível comprovar in absentia a participação de sufixos derivacionais nas chamadas derivações regressivas.

Bauer (1983:22) adota a posição de Gruber, que vê na interpretação unificada da derivação sufixal e da derivação zero uma generalização proveitosa para a descrição lingüística:

"GRUBER (1976:337 F), por exemplo, argumenta que tratar de maneira diferente a derivação normal e a derivação-zero é perder uma generalização, uma vez que ambas envolvem mudanças de classes formais, mas afirma que elas só podem ser tratadas da mesma maneira, se for admitido o sufixo zero. Caso contrário, diz ele, a derivação pode ser interpretada como um processo governado por regras, mas a derivação-zero não pode..."

Há casos em que as formas nominalizadas são doublets, o que vem confirmar o nosso raciocínio, uma vez que o substantivo pode ser operacionalizado através de sufixo implícito ou explícito:

$\begin{array}{lll}\text { patrulhar } & \text { patrulha } & \text { patrulhamento } \\ \text { agitar } & \text { agito } & \text { agitação } \\ \text { apertar } & \text { aperto } & \text { apertura } \\ \text { apoiar } & \text { apoio } & \text { apoiamento } \\ \text { argumentar } & \text { argumento } & \text { argumentação }\end{array}$




\begin{tabular}{|c|c|c|}
\hline consolar & consolo & consolação \\
\hline detalhar & detalhe & detalhamento \\
\hline distanciar-se & distância & distanciamento \\
\hline encaixar & encaixe & encaixamento \\
\hline incentivar & incentivo & incentivação \\
\hline iniciar & início & iniciação \\
\hline fugir & fuga & fugida \\
\hline marcar & marca & marcação \\
\hline melhorar & melhora & melhoria/melhoramento \\
\hline improvisar & improviso & improvisação \\
\hline visitar & visita & visitação \\
\hline votar & voto & votação \\
\hline despistar & despiste & despistamento \\
\hline eclamar & reclame & reclamação \\
\hline
\end{tabular}

A linguagem jornalística registra com freqüência exemplos dessa indecisão entre a forma com sufixo explícito e a forma com sufixo zero. Observamos recentemente restauro (por restauração) e enrosco (por enroscamento). Em um mesmo texto jornalístico, encontramos realizações de duas possibilidades (Estado de Minas, 30/10/90, p.1):

"Rio Verde seca com o desmate.

O desmatamento na Serra da Mantiqueira é um das principais causas da diminuição do volume de água do Rio Verde." (Título da matéria seguida do texto)

Em determinados contextos, observa-se que é possível empregar formas sufixadas não-ortodoxas, no lugar de derivaçõeszero consagradas:

Este ato de censuramento merece a nossa repulsa.

Com aquele atrasamento mal feito, até eu faria o gol.

O colecionamento de selos é uma tarefa do espírito.

Só é possível fazer o contornamento da montanha com a ajuda de um guia. 
Você não pode viver nessa duvidação a vida toda!

Para contar uma história, ele faz uma exageração danada.

Naqueles casos em que a norma lexical não aceita as formas sufixadas, é possível interpretar, hipoteticamente, os regressivos como portadores de sufixo zero, equivalente a sufixo explícito. Observe-se que os chamados regressivos funcionam na língua como se fossem formações com sufixos palpáveis:

$\begin{array}{ll}\text { abandono }+\varnothing & \text { (?)abandonamento } \\ \text { ameaça }+\varnothing & \text { (?)ameaçamento } \\ \text { choque }+\varnothing & \text { (?)chocamento } \\ \text { conquista }+\varnothing & \text { (?)conquistamento } \\ \text { crítica }+\varnothing & \text { (?) criticamento } \\ \text { disputa }+\varnothing & \text { (?)disputação } \\ \text { entregar }+\varnothing & \text { (?)entregação }\end{array}$

Em síntese, a respeito da nominalização zero pode-se afirmar que: a - Enquadra-se no padrão sufixal, $\mathrm{V} \Rightarrow[$ [V] -suf] $\mathrm{N}$.

b - A língua operacionaliza a nominalização através de sufixos variados, dentre eles, -ção, -mento, -agem, -nça, -ura. A língua operacionaliza a nominalização também através do sufixo zero, que corresponde a 23,4\% dos casos na lista de Basílio (104 ocorrências em 443). A rigor, não se deve dizer que uma forma como preparo, por exemplo, não apresenta sufixo, mas, sim, que ela apresenta sufixo zero, do mesmo modo como se afirma que livro está no singular, porque apresenta a desinência zero, ou, como se diz vulgarmente, porque não apresenta o -s. O mesmo raciocínio pode ser aplicado a cantava: está na $1^{\underline{a}}$ ou $3^{\underline{a}}$ pessoa do singular por apresentar o sufixo zero (em contraste com cantavas ou cantávamos, por exemplo);

c - Do mesmo modo como se dá com as nominalizações explícitas, os nominais zero são nomes abstratos, referem-se ao 'ato ou ação de X'. 
Com o exposto, estamos tentando contribuir para a resolução de um problema antigo em nossas gramáticas, que é o da direcionalidade do processo. Cunha e Cintra (1985:103), por exemplo, afirmam:

"Nem sempre é fácil saber se o substantivo deriva do verbo ou se este se origina do substantivo. Há um critério prático para a distinção, sugerido pelo filólogo MÁRIO BARRETO: 'Se o substantivo denota ação, será palavra derivada, e o verbo palavra primitiva; mas, se o nome denota algum objeto ou substância, se verificará o contrário.' (De Gramática e de Linguagem, II, Rio de Janeiro, 1922, p. 247.) Assim: dança, ataque e amparo, denotadores, respectivamente, das ações de dançar, atacar e amparar, são formas derivadas; âncora, azeite e escudo, ao contrário, são formas primitivas, que dão origem aos verbos ancorar, azeitar e escudar."

A proposta de Mário Barreto tem sofrido restrições por parte de alguns autores, dentre eles, BASÍLIO (1987:41), que afirma:

"O problema é que essa distinção não cobre a grande maioria de pares desse tipo, em que a forma de substantivo nem é ação nem é um objeto concreto, facilmente reconhecível como tal, ou uma substância."

Em seguida, a autora cita atraso e demora, que não correspondem a ações e muito menos a objetos concretos ou substâncias.

Embora haja coincidência entre a posição de Mário Barreto e a nossa, a proposta do filólogo apresenta o inconveniente de se apoiar em um critério semântico que apresenta falhas, como demonstrou Basílio. A nossa proposta é formal, pois se apóia na existência do sufixo nominalizador, que pode ser explícito ou implícito. As correspondências abaixo parecem ilustrar bem a questão:

$\begin{array}{lll}\text { parafuso } & \text { parafusar } & \text { parafusamento } \\ \text { azeite } & \text { azeitar } & \text { azeitamento } \\ \text { âncora } & \text { ancorar } & \text { ancoramento }\end{array}$

Parafuso, azeite e âncora, por serem concretos, e por não apresentarem sufixo explícito ou implícito, são primitivos. Deles derivam-se parafusar, azeitar e ancorar. Por sua vez, parafusamento, azeitamento e ancoramento, nomes abstratos, são as contrapartes nominais dos verbos, devidamente sufixadas. 
Pelos motivos apontados neste trabalho, somos inclinados a interpretar os chamados regressivos como derivados de verbos. Em resumo, pode-se dizer: dado um verbo, deve-se prever a existência de um substantivo abstrato correspondente, seja através de sufixação explícita, seja através de sufixação implícita (zero).

\section{SUFIXÓIDE}

Sabemos que o sufixo possui como característica essencial a recorrência, ou seja, um sufixo tem a propriedade de ser anexado a bases distintas para formar outras palavras, que possuirão características comuns, provenientes desse sufixo. Um sufixo derivacional pode, portanto, ser definido como uma forma lingüística presa, recorrente, que é anexada à direita da raiz, com o objetivo de formar uma nova palavra. Mas existem "falsos sufixos", ou seja, formas lingüísticas presas, que são anexadas à direita da raiz, com o objetivo de formar uma nova palavra, diferindo dos verdadeiros sufixos apenas pelo fato de serem formas lingüísticas não-recorrentes. Em casebre, por exemplo, a forma lingüística -ebre só é um sufixo aparentemente. Trata-se de uma forma não-recorrente, que só aparece na palavra casebre. Sendo uma forma não-recorrente, não é, portanto, um sufixo, mas um sufixóide (Rocha, 1998).

Os sufixóides apresentam as seguintes características:

- são formas lingüísticas presas e não-recorrentes;

- são anexados a bases ao mesmo tempo livres e puras;

- apresentam um sentido exclusivo, específico, não-previsível;

- são formas lingüísticas improdutivas.

Seguem-se alguns exemplos de formações com sufixóide, que não sejam nominalizações: bichano, urinol, pedestre, cursilbo, papelote, andarilho, sertanejo, marujo, marisco, cantarolar, choramingar, cartilha, mulherengo, patriota, longinquo, etc.

$\mathrm{Na}$ lista de Basílio aparecem os seguintes nominais com sufixóide: cansaço, comentário e tentativa. 
Citam-se também como exemplos de nominais sufixoidais: canseira, sumiço e decoreba.

Embora o reconhecimento dos sufixóides não traga maiores benefícios para o estudo da produtividade lexical, uma vez que eles são irrecorrentes, o que vale dizer, improdutivos, a sua caracterização é importante, porque nos aponta a verdadeira distinção entre sufixos verdadeiros e falsos sufixos, além de mostrar a "fundamental importância de se distinguir as formas já feitas dos processos de formação" (Basílio, 1987:25).

\section{CONDIÇÕES DE PRODUTIVIDADE: OS SUFIXOS -ÇÃO, ZERO E -MENTO}

Dentre os sufixos nominalizadores, -ção, zero e -mento estão entre os mais produtivos. A listagem de Basílio, formada de 443 exemplos, apresenta os seguintes dados:

$\begin{array}{lcc}\text { SUFIXO } & \text { QUANTIDADE } & \% \\ \text {-ção } & 168 & 37,9 \\ \text { zero } & 104 & 23,4 \\ \text {-mento } & 58 & 13,0 \\ \text {-ncia, -nça } & 27 & 06,0 \\ \text {-da, -do } & 14 & 03,1 \\ \text {-agem } & 08 & 01,8 \\ \text {-ura } & 06 & 01,3 \\ \text { sufixóides } & 04 & 00,9 \\ \text { outros } & 03 & 00,6\end{array}$

Observe-se que os sufixos -ção, zero e -mento respondem, em conjunto, por $74,3 \%$ dos casos, ou seja, por $3 / 4$ das nominalizações

A listagem de Basílio apresenta ainda 10 casos de lexicalização (defesa, dito, dor, excesso, posse, promessa, resposta, surpresa, valor e vitória) e 4 de conversão, ou seja, derivação imprópria (atingir, jantar, mexere murchar). Em separado, não fazendo parte do total de 443 casos, a autora apresenta uma lista de 37 verbos que não possuem a contraparte nominal (achar, aguardar, agüentar, botar, 
constar, ficar, levar, ser, etc.). Na seção 4 deste trabalho, discutiu-se por que certos verbos não apresentam a contraparte nominal.

Os sufixos -ção, zero e -mento, além de integrarem inúmeros itens já cristalizados na língua, participam da formação de várias palavras novas, o que comprova a sua elevada produtividade no português contemporâneo.

Para o estudo das condições de produtividade desses sufixos, torna-se necessário examinar as características da base, o que será feito nos parágrafos que se seguem.

De acordo com a literatura referente ao estudo das nominalizações (Basílio, 1990:3, Albino, 1993:14), sabe-se que as bases derivadas com os sufixos -izar e -ficar apresentam formações nominalizadas em -ção. As bases derivadas com o sufixo -ecer apresentam o nominal correspondente com o sufixo -mento:

realizar/realização

mexicanizar/mexicanização

amplificar/amplificação

normificar/normificação entristecer/entristecimento envelhecer/envelhecimento esclarecer/esclarecimento florescer/florescimento

Tudo indica, porém, que a categorização da base não leva em conta apenas características ou traços morfológicos, mas também, traços fonológicos. Tanto é verdade que bases com a terminação - i CClar ( $C=$ consoante) e -ecer, mesmo que sejam bases primitivas, combinam com os sufixos -ção e -mento, respectivamente, como nos exemplos:

$-i[C] \operatorname{ar} /-c ̧ \tilde{a} O$

abominar/abominação aspirar/aspiração, complicar/complicação excitar/excitação implicar/implicação motivar/motivação animar/animação ativar/ativação destinar/destinação explicar/explicação indicar/indicação participar/participação antecipar/antecipação, citar/citação, dominar/dominação, fascinar/fascinação humilhar/humilhação publicar/publicação 
-ecer/-mento

acontecer/acontecimento agradecer/

comparecer/

agradecimento

conhecer/conhecimento

comparecimento

crescer/crescimento

esquecer/esquecimento

falecer/falecimento oferecer/oferecimento vencer/vencimento

Como se vê, trata-se de condicionamento fonológico e não, morfológico.

Quando a base não termina em -i [C] ar ou -ecer, é difícil prever se ela combina com -ção, zero ou -mento. Na lista de Basílio, os 267 exemplos de verbos que não terminam em -i [C] ar e -ecerapresentam o seguinte quadro:

-ção: 124 casos - 46,4\% (adoração, alteração, anexação, apresentação, arrumação, atrapalhação, cassação, colocação, comemoração, obtenção, destituição, etc.)

zero: 102 casos - 38,2\% (abandono, acerto, ajuda, ameaça, aperto, apoio, argumento, arranjo, atraso, aumento, consolo, desempenho, trabalho, etc.)

-mento: 41 casos - 15,3\% (acompanhamento, adiantamento, aproveitamento, atendimento, depoimento, divertimento, entupimento, julgamento, lançamento, etc.)

O que se constata, portanto, é que a formação de nominais com -ção, zero e -mento está relacionada com a caracterização fonológica da base e pode ser assim resumida:

Bases terminadas em $-i[C]$ ar

Bases terminadas em -ecer

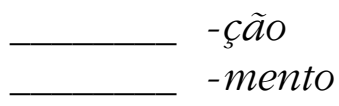

Bases com outras terminações sufixos variados

Partindo-se da listagem de Basílio observam-se os dados que se seguem. 


\subsection{Verbos com a terminação em -i [C] ar}

De um total de 51 casos observa-se o seguinte:

38 nominalizações com -ção

$(74,5 \%)$

9 nominalizações com zero

$(17,6 \%)$

1 nominalização com -mento

3 nominalizações com outros sufixos $(5,8 \%)$

O que se comprova, portanto, é que o sufixo nominalizador ção é nitidamente sensível a verbos com a terminação -i [C]ar, seja essa terminação sufixo ou não. Os dados abaixo, baseados ainda na listagem de Basílio, comprovam o que acabamos de dizer: o sufixo nominalizador -ção combina tanto com verbos derivados (19 casos), quanto com verbos não-derivados (19 casos):

Verbos derivados com o sufixo -izar: 12

Verbos derivados com o sufixo -ficar. $06 \quad$ Total: 19

Verbos derivados com o sufixo -icar. 01

Verbos não-derivados: 19 (abominar, agitar, antecipar, aspirar, ativar, citar, complicar, destinar, dominar, explicar, fascinar, implicar, indicar, indignar-se, motivar, obrigar, participar, positivar, publicar)

Como se vê, a formação de nominais em -ção está, em parte, condicionada a fatores fonológicos, e não, morfológicos.

\subsection{Verbos com a terminação em -ECER}

$\mathrm{Na}$ lista de Basílio, de um total de 17 casos, observam-se os seguintes dados:

16 nominalizações com -mento $(94,1 \%)$

01 nominalização com -ncia (5,9\%) (permanecer/permanência)

Não há nominalizações com -ção e zero. 
Por sua vez, as 16 nominalizações com -mento apontadas acima apresentam o seguinte tipo de base:

Verbos com o sufixo -ecer: 6 casos (agradecer, entristecer, envelhecer, esclarecer, estabelecer, estremecer)

Verbos primitivos: 8 casos (acontecer, aparecer, conhecer, convencer, crescer, esquecer, oferecer, vencer)

Pelos dados apresentados, vê-se que os nominais em -mento são particularmente sensíveis a bases terminadas em -ecer, quer se trate de sufixo ou não. Na lista de Basílio, 6 bases com -ecersão com sufixos e 8 bases são primitivas, o que vem comprovar o que dissemos anteriormente: o condicionamento não é morfológico, mas, fonológico.

\section{O SUFIXO -ÇÃO ITERATIVO}

Nesta seção trataremos do sufixo nominalizador -ção, acrescido de um componente semântico específico, que não ocorre com os outros sufixos nominalizadores. Consideramos portanto a existência de um sufixo que denominamos de -ção iterativo, caracterizado por sua ocorrência exclusiva no linguajar informal, apresentando como propriedade semântica a idéia de iteratividade, além da idéia consagrada de 'ato de X'. Observemos algumas sentenças que ilustram essa ocorrência:

Parem com essa bateção de porta!

Não suporto a xingação de professores todo dia.

Mas que chamação irritante!

Há uma colação generalizada na aula de Geografia.

Vocês têm que parar com essa faltação de aula.

Procedemos a uma análise detalhada desse sufixo, buscando depreender, a partir da lista de Basílio, que verbos aceitariam esse sufixo. Eis alguns exemplos: 


$\begin{array}{llll}\text { abrir } & \text { abrição } & \text { falar } & \text { falação } \\ \text { abanar } & \text { abanação } & \text { fechar } & \text { fechação } \\ \text { chorar } & \text { choração } & \text { jogar } & \text { jogação } \\ \text { comprar } & \text { compração } & \text { lavar } & \text { lavação } \\ \text { contar } & \text { contação } & \text { mandar } & \text { mandação } \\ \text { estudar } & \text { estudação } & \text { vender } & \text { vendeção }\end{array}$

Partindo desse estudo, observamos que a grande maioria dos verbos aceita o -ção iterativo, amplamente empregado em conversas informais diárias. Entretanto, há algumas formações verbais que não aceitam esse sufixo nominalizador, como veremos a seguir.

\subsection{Verbos que não aceitam o -ção iterativo}

\subsubsection{Verbos que apresentam o -ção neutro}

As formas nominalizadas institucionalizadas que recebem o -ção neutro não admitem o -ção iterativo.

Pelo fato de apresentarem um sentido e um emprego já consagrados na língua, o componente semântico secundário de 'repetição' não será atribuído a elas. Acrescente-se ainda o fato de essas formações serem usadas em qualquer modalidade de língua (tensa ou distensa), o que as impede de serem empregadas exclusivamente na língua coloquial, como acontece com o -ção iterativo. Portanto, verbos que apresentam nominais consagrados em -ção neutro, não aceitam o -ção iterativo, como nos exemplos: preparar/preparação, consagrar/consagração, confirmar/confirmação, realizar/realização, iniciar/iniciação, preocupar/preocupação, etc.

Por outro lado, é interessante observar que verbos com nominais lexicalizados que apresentam o -ção neutro, poderão também receber o -ção iterativo, desde que passem por uma recuperação morfológica (cf. c. o item 5.4). Natação é o nominal consagrado, lexicalizado, de nadar. É possível recuperar a transparência morfológica da formação nominalizada, como em:

- Luísa, para com essa nadação o dia todo ! 
Nos exemplos que se seguem, já citados anteriormente, observa-se a recuperação morfológica de nominais lexicalizados com o sufixo -ção ou não - com o intuito de se empregar o -ção iterativo:

O governo precisa parar com essa concedeção de medalha. (por concessão)

O padre não tem sossego. Fica essa confessação o dia inteiro. (por confissão)

Houve uma discutição danada, durante a noite toda. (por discussão)

O candidato precisa parar com essa prometeção, senão ele vai se dar mal. (por promessa)

Até que enfim, o diretor parou com a suspendeção de alunos. (por suspensão)

Você precisa parar com essa viajação o mês inteiro! (por viagem)

\subsubsection{Verbos monossilábicos}

Os verbos monossilábicos da língua portuguesa (ir, crer, ter, vir, ler, ser, dar, pôr e ver) não aceitam o -ção iterativo: *ição (de ir), *creção (de crer), *teção (de ter), *vição (de vir), *leção (de ler), etc. Parece tratarem-se de formas não-naturais. Outros fatores podem contribuir para a não-aceitação de nominais derivados de verbos monossilábicos, como o bloqueio homofônico, por exemplo (*seção/ seçâo, *poção/poção). Mesmo assim, cremos ser possível isolar o problema e considerá-lo mais geral, uma vez que todos as bases em questão não aceitam o respectivo nominal.

Alguns verbos da lista acima admitem o -ção neutro (mas não o iterativo), a partir do momento em que deixam de ser monossilábicos. São os derivados de ter (reter/retenção, abster/abstenção, deter/detenção, conter/contenção, obter/obtenção - mas ater/ (?)atenção, entreter/(?)entretenção), os derivados de pôr (compor/ composição, depor/deposição, interpor/interposição, opor/oposição, 
pospor/posposição, repor/reposição, transpor/transposição), além de intervir, derivado de vir (intervenção), mas convir/(?)convenção. Posição, derivado de pôr, não é a forma nomina-lizada desse verbo, uma vez que não indica o 'ato de pôr', como se comprova pela "reprovação" no teste a que nos referimos na seção 3:

(?)Os funcionários vão pôr os sapatos nas estantes. A posição dos sapatos durará cerca de duas horas.

\subsubsection{Verbos usados em linguagem formal}

Uma vez que o -ção iterativoé próprio da linguagem coloquial, os verbos próprios da linguagem formal, utilizados em textos técnicos, científicos, jornalísticos, etc. - não o admitem. Vejamos alguns deles:

desempenhar, aconselhar, exceder, gerir, incumbir, presidir, surpreender, depor, ocorrer, presidir, resistir, tolerar, convir, decair, existir, falir, prosseguir, censurar, tolerar, desistir, etc.

\subsubsection{Verbos que indicam estado}

Os verbos que indicam estado - alguns deles com função copulativa - não aceitam o -ção iterativo, por apresentarem o caráter de permansividade. Pelo fato de não serem verbos de ação, os conteúdos semânticos veiculados não são passíveis de repetição. Constatam apenas a existência de um sentimento, sensação ou situação.

Esses verbos não admitem ser caracterizados por expressões do tipo: várias vezes, muitas vezes, repetidamente, etc. Observemse os exemplos:

* No Chile existem várias vezes vulcões.

* Os cangurus possuem muitas vezes bolsas para abrigar os filhotes. 
* Amai-vos várias vezes uns aos outros.

* A rosa é repetidamente vermelha.

Verbos como existir, possuir, amar, permanecer e ser não aceitam, portanto, o -ção iterativo.

Um mesmo verbo pode indicar estado ou ação, dependendo do contexto:

Os atleticanos odeiam os cruzeirenses, e vice-versa.

Muitas vezes eu odeio o Jornal Nacional

\subsubsection{Verbos atributivos}

Os verbos atributivos são aqueles que especificam características de elementos inanimados em geral, como mostram os exemplos abaixo:

Aquela fruta pesa 3 quilos.

O tecido mede 2 metros.

A carne custa 5 reais.

Como o próprio nome indica, são verbos empregados para atribuir características, sendo essa sua única função nesses casos. Portanto, o emprego do -cão iterativo não lhes cabe, pois o sentido de 'ato de X', acrescido da idéia de repetição e do emprego exclusivo em linguagem informal (que este sufixo nominalizador apresenta) não compete aos verbos atributivos. São eles:

pesar, medir, caber, custar, valer, etc.

Os três primeiros verbos, pesar, medire caber, quando não são empregados com o sentido atributivo, ou seja, quando são verbos de ação, aceitam o -cão iterativo:

- Gordinha, pare com esse pesação todo dia!

- O vovô arruma uma medição de pressão! 


\subsubsection{Verbos terminados em -cionar, -cinar e -ciar}

Os verbos terminados em -cionar,-cinar e -ciar não aceitam o -ção iterativo por razões fonológicas, uma vez que formações aliteradas em -cionação, -cinação e -ciação são evitadas pelos falantes, como podemos verificar em (?)condicionação, (?)raciocinação e (?)influenciação. Citam-se ainda como exemplos:

emocionar, selecionar, revolucionar, raciocinar, relacionar, colecionar, condicionar, lecionar, mencionar, patrocinar, vaticinar, distanciar, silenciar, influenciar, financiar, etc.

\subsubsection{Verbos terminados em -ecer}

Vimos na seção 9 que verbos terminados em -ecer não favoráveis à formação de nominais em -mento (aquecimento, oferecimento, envelhecimento, etc.). Pelo fato de não aceitarem, via de regra, o -ção neutro, esses verbos também não aceitarão o -ção iterativo. São verbos do tipo: acontecer, agradecer, conbecer, estabelecer, oferecer, reconbecer, amadurecer, envelhecer, escurecer, etc.

\subsubsection{Outras observações}

Conforme destacamos anteriormente, quase todos os verbos da língua portuguesa aceitam o -ção iterativo, independentemente de possuírem, ou não, a forma nominalizada correspondente (abrir/ abertura/abrição, quebrar/quebra/quebração, morrer/morte/ morreção; pendurar/ - /penduração, tirar/ - /tiração, etc.) Isso se explica pelo fato de que a grande maioria dos verbos exprime ação e, como sabemos, a ação é, via de regra, passível de repetição. É o caso de bateção, xingação, faltação, mandação, falação, dentre outros, que se referem a um ou vários elementos animados ou inanimados.

O fato de um verbo com o -ção iterativo referir-se a um sujeito coletivo ou não, pode afetar a sua aceitabilidade: 
Está uma nasceção de meninos na Santa Casa!

* É preciso parar com a nasceção desse menino!

Está ocorrendo uma morreção de animais este ano!

* A morreção de fulano já está preocupando muita gente!

Não sei por quê, mas está uma enterração de gente neste cemitério!

* Eles não param com a enterração daquele homem!

As frases com asterisco não são aceitáveis, porque um mesmo ser pode nascer, morrer ou ser enterrado apenas uma única vez, não sendo, portanto, lógico atribuir a ele a idéia de repetição nesses casos.

Para finalizar, torna-se imprescindível frisar que o -ção iterativo e o -ção neutro são um único sufixo, pois ambos apresentam o mesmo aspecto formal - a criação de formas nominalizadas a partir de verbos -, e o mesmo sentido básico de 'ato, efeito, fato, estado, processo, evento, modo ou resultado de X'. A diferença entre eles está na "semântica de segundo grau", uma vez que as formas com o -ção iterativo, além de possuírem o significado próprio das formações nominalizadas, apresentam extensão de sentido, que é a idéia de repetição. A língua portuguesa apresenta alguns derivados com semântica de segundo grau. Veja-se o caso das formações novas com o sufixo -eiro: além de indicarem a idéia de 'agente', são também nomes pejorativos: noveleiro, treineiro, sacoleiro, roqueiro, marqueteiro, micreiro, etc. Para maiores informações, consulte-se especialmente Frota (1985).

\section{NOMINALIZAÇÃO E DISCURSO}

Existe uma relação entre certas RFP's e determinados tipos de texto. Antes de examinarmos essa questão com relação à nominalização, vamos citar alguns exemplos em que o tipo de texto pode influenciar nas condições de produção de alguns processos de formação de palavras. 
Consideremos primeiramente o caso das RFP's com os sufixos avaliativos (-inho e -ão). De um modo geral, todo substantivo pode servir de base para a aplicação das regras em questão. São poucos os substantivos que não aceitam a anexação desses sufixos. Embora as regras sejam extremamente regulares, observa-se que na chamada língua padrão (ténica, científica, burocrática, etc.) há uma restrição muito forte a formações com os sufixos que a GT chama de diminutivos ou aumentativos. De fato, em uma tese de doutorado em Física, por exemplo, não se encontram formações do tipo: vacuozinho, atritinho, vetorzão ou forçona. Dá-se, portanto, o que se chama de restrição discursiva (cf. c. Rocha, 1998).

Em segundo lugar, analisemos o caso dos produtos da RFP $\mathrm{N} \Rightarrow[\mathrm{N}]$-aiada] N. Como sabemos, em português existe tradicionalmente o sufixo -ada, formador de nomes com o sentido de 'conjunto, reunião' (boiada, criançada, buracada, etc). No português atual, esse sufixo sofre forte concorrência do sufixo -ada, com o sentido de 'golpe, gesto brusco', como em peitada, reguada, mochilada, etc. Para evitar esse choque homofônico, a linguagem popular tem utilizado -aiada, que é um sufixo alomórfico de -ada (de boiada). Surgem palavras do tipo: vidraiada, camisaiada, livraiada, nomaia$d a$, etc. Trata-se, como dissemos, de formações características de discursos coloquiais.

Uma última série de exemplos pode ser dada com formações com o sufixo -idade, que são características de discursos formais. É o que se dá com produtos do tipo: temporalidade, aleatoriedade, idealidade, univocidade, praticidade, contemporaneidade, cotidianidade, etc.

Para tratarmos da relação entre a nominalização e o tipo de discurso, vamos tentar responder a duas perguntas, ambas relacionadas com dois tipos de discurso: o dissertativo e o narrativo:

$1^{\text {a }}$ - Que tipo de texto á mais favorável à nominalização: o dissertativo ou o narrativo?

$2^{a}$ - Existe alguma relação entre o tipo de texto e o uso de determinado sufixo nominalizador? 


\subsection{Nominalização e tipo de discurso}

Os autores que tratam do assunto são acordes em afirmar que o discurso formal é mais favorável ao emprego de nominais do que o discurso informal (Barreto, 84; Albino, 93; Basílio, 96).

Resolvemos fazer um levantamento nesses dois tipos de texto para verificar se essa hipótese se confirma e, em caso positivo, em que proporções ela se confirma.

No caso dos textos dissertativos, tomamos como corpus diversos trechos de artigos variados publicados na revista Caminhos, editada pela APUBH (Associação dos Professores Universitários de Belo Horizonte), no 14, junho de 1997. Os autores são professores universitários e os artigos tratam de assuntos que exigem uma abordagem dissertativa, tais como: o papel da universidade brasileira, a autonomia universitária, questões concernentes à educação, etc.

Com relação aos textos narrativos, fixamos como córpus trechos diversos extraídos das obras infanto-juvenis abaixo:

DUPRÉ, Maria José. A ilha perdida. São Paulo: Ática, 1973.

HOMEM, Homero. Cabra das Rocas. São Paulo, Ática, 1973.

MONTEIRO, José Maviel. Os barcos de papel. São Paulo, Ática, 1984.

REY, Marcos. Dinheiro do céu. São Paulo: Ática, 1985.

MOTT, Odete de Barros. A grande ilusão. São Paulo: Brasiliense, 1981.

Cada uma das modalidades textuais apresentou um total de 3.000 palavras. Os resultados são apresentados a seguir:

Tipo de texto № de palavras № de nominais Porcentagem

$\begin{array}{lrrr}\text { Dissertativo } & 3.000 & 161 & 5,13 \% \\ \text { Narrativo } & 3.000 & 59 & 1,72 \%\end{array}$

Como se vê, o texto dissertativo é mais favorável ao emprego de formas nominalizadas, numa proporção de 3 por 1 (aproximadamente). 
Como se pode explicar o número maior de formações nominalizadas no texto dissertativo do que no texto narrativo?

Começando pelo texto narrativo, diremos que ele se caracteriza pelo fato de apresentar seqüências de eventos, ou seja, seqüências que se localizam no eixo do tempo. Ora, a categoria lexical que melhor se presta para a expressão do tempo é, sem dúvida alguma, o verbo. Daí a preferência da narrativa pelo verbo.

Já o texto dissertativo caracteriza-se pelo fato de apresentar dados, idéias, conceitos, raciocínios, conclusões, etc. Dá-se uma combinação desses elementos para se produzir conhecimento objetivo. A categoria lexical que se presta melhor à expressão de noções estáticas é o nome. Daí a preferência do texto dissertativo pela formação nominalizada.

Como no texto dissertativo o importante é a produção do conhecimento objetivo, e o enunciador passa a ter uma importância secundária, diremos, com Albino (1993:37), que o uso de nominalizações nos textos dissertativos constitui "...um modo de esconder o enunciador e de conceder ao texto o caráter objetivo, neutro e impessoal que lhe convém, procurando dirigir a atenção do leitor apenas para o ato ou processo em si”.

\subsection{Tipo de discurso e preferência por formações sufixais}

A segunda pergunta a que nos propusemos responder é: existe alguma relação entre o tipo de texto e o uso de determinado sufixo nominalizador?

Os dados encontrados na pesquisa são os seguintes:

$\begin{array}{lccc}\text { Sufixos } & \begin{array}{c}\text { TD - Texto } \\ \text { dissertativo }\end{array} & \begin{array}{c}\text { TN }- \text { Texto } \\ \text { narrativo }\end{array} & \text { Diferença } \\ \text { zero } & 39,1 \% & 45 \% & +5,9 \% \text { (TN) } \\ \text {-ção } & 36,6 \% & 33,8 \% & +2,8 \%(\mathrm{TD}) \\ \text {-mento } & 12,4 \% & 5 \% & +7,4 \%(\mathrm{TD}) \\ \text { outros } & 11,8 \% & 15,2 \% & +3,4 \% \text { (TN) }\end{array}$


Como podemos verificar, a última coluna da direita demonstra a diferença a favor do tipo de texto indicado por TN ou TD.

A análise dos dados nos permite fazer as seguintes observações:

a) O sufixo zero é o mais empregado tanto no TD quanto no TN. Os textos narrativos são um pouco mais favoráveis $(5,9 \%)$ ao emprego desse sufixo.

b) Em segundo lugar aparece o sufixo -ção, nos dois tipos de texto, com um ligeiro predomínio $(2,8 \%)$ no texto dissertativo.

c) O sufixo -mento aparece em terceiro lugar no TD e em quarto lugar no TN. Pode-se concluir que os textos dissertativos são mais favoráveis $(+7,4 \%)$ ao emprego de formas nominais com o sufixo -mento.

\section{CONCLUSÃO}

Na introdução deste trabalho, dissemos que o nosso objetivo era o de "demonstrar que o léxico português, sob o ponto de vista de sua estruturação morfológica, constitui um conjunto harmonioso, funcional e sistemático, com tendências, constâncias ou, mais especificamente, regras, que fornecem a essa estrutura princípios gerais de organização". Para a consecução desse objetivo, procuramos analisar o fenômeno morfológico da nominalização em português. Após conceituar esse fenômeno e apresentar as bases teóricas sobre as quais trabalharíamos, pudemos estudar algumas das suas características mais importantes, como: a questão do bloqueio, o fato de alguns verbos não apresentarem a contraparte nominal, a lexicalização, a produtividade dos principais sufixos nominalizadores, a derivação sufixal zero e um caso especial de extensão de sentido, que denominamos de verbos com -ção iterativo. Procuramos concentrar nossos esforços em certos pontos que nos parecem pouco estudados em português ou para os quais as soluções são conflitantes. Longe da pretensão de querer ter resolvido o assunto, gostaríamos de realçar os seguintes aspectos: a apresentação de um teste para caracterizar o fenômeno da nominalização; a tentativa de 
abordar a questão do desbloqueio; o estudo da lexicalização; a abordagem específica da nominalização zero, as condições de produtividade dos sufixos -ção, -mento e zero e uma reflexão especial sobre o -ção iterativo. Essas questões a respeito da nominalização nos levaram a concluir que, apesar de apresentar inúmeros casos de idiossincrasia, o léxico português, sob o ponto de vista de sua estruturação morfológica, constitui, de fato, um conjunto harmonioso, funcional e sistemático, com regras que fornecem a essa estrutura princípios gerais de organização.

\section{NOTA}

* Este trabalho contou com a colaboração da bolsista de Iniciação Científica (FAPEMIG) Rachel Frância Maia, aluna da FALE/UFMG, em 1996-1997.

\section{REFERÊNCIAS BIBLIOGRÁFICAS}

ALBINO, José Mauro Branco. As condições de produção dos sufixos nominalizadores -ção e-mento no português escrito formal. Rio de Janeiro: UFRJ, 1993. (Dissertação, Mestrado em Lingüística).

ALVES, Ieda Maria. Neologismo; criação lexical. Rio: Ática, 1990.

ANDERSON, Stephen R. A-morphous morphology. Cambridge: Cambridge University Press, 1992.

ARONOFF, Mark. Word formation in generative grammar. Cambridge: The MIT Press, 1976.

AZEVEDO, João Luiz Ferreira de. A questão do agente nas construções nominalizadas no discurso escrito em português. Rio de Janeiro: UFRJ, 1991. (Dissertação, Mestrado em Lingüística).

BARRETO, Beatriz de Castro. A nominalização no texto dissertativo: um estudo dos padrões sintáticos. Rio de Janeiro: PUC, 1984. (Dissertação, Mestrado em Letras).

BASÍLIO, Margarida. Estruturas lexicais do português; uma abordagem gerativa. Rio de Janeiro: Ática, 1980.

- Relevância do fator semântico na descrição de processos de formação de palavras: um estudo das formas X-agem em português. In: ENCONTRO NACIONAL DE LINGÜÍSTICA, 7, 1984. Rio de Janeiro: PUC, p.96-101, 1984. 
. Formação e uso da nominalização deverbal sufixal no português falado. In CASTILHO, Ataliba Teixeira de, BASÍLIO, Margarida (Orgs.) Gramática do Português falado; V. IV: Estudos descritivos. Campinas: Edit. da UNICAMP, p.23-33, 1996.

. et al. Derivação, composição e flexão no português falado: condições de produção. In CASTILHO, Ataliba Teixeira de (Org.) Gramática do Português falado; V. III: As abordagens. Campinas: Edit. da UNICAMP, p.363-429, 1996.

BAUER, Laurie. English word-formation. Cambridge: Cambridge University Press, 1983.

CHOMSKY, Noam. Remarks on nominalization. Readings in english transformational grammar. Walthan: Ginn and Co., 1970.

CORBIN, Danielle. Morphologie dérivationelle et structuration du lexique. 2 v. Tübingen: Max Niemeyer, 1987.

CUNHA, Celso, CINTRA, Lindley. Nova gramática do Português contemporâneo. Rio de Janeiro: Nova Fronteira, 1985.

FROTA, Maria Paula. A expressão do pejorativo em construções morfológicas. Rio de Janeiro: PUC, 1985. (Dissertação, Mestrado em Letras).

GAMARSKI, Lea. A derivação regressiva: um estudo da produtividade lexical em Português. Rio de Janeiro: UFRJ, 1984. (Tese, Doutorado em Lingüística).

GUNZBURGER, L. Previsibilidade semântica em nominais correspondentes a verbos intransitivos. Rio de Janeiro: PUC/RJ, 1979 (Mestrado em Lingüística)

KATAMBA, Francis. Morphology. Houndmilla: The Macmillan Press, 1993.

MEYER, Rosa Marina de Brito. A complementação da forma nominalizada deverbal sufixal e a conceituação do complemento nominal. Rio de Janeiro: PUC/RJ, 1991. (Tese, Doutorado em Lingüística).

ROCHA, Luiz Carlos de Assis. Estruturas morfológicas do Português. Belo Horizonte: Editora UFMG, 1998.

. Guimarães Rosa e a terceira margem da criação lexical. In MENDES, Lauro Belchior, OLIVEIRA, Luiz Cláudio Vieira de. (Orgs.) A astúcia das palavras. Belo Horizonte: Ed. UFMG, p. 81-100, 1988.

ROSA, João Guimarães. Grande sertão: veredas. 5.ed. Rio de Janeiro: José Olympio, 1967.

. Primeiras estórias. 6.ed. Rio de Janeiro: José Olympio, 1972.

SANDMANN, Antônio José. Formação de palavras no português brasileiro contemporâneo. Curitiba: Scientia et Labor, 1988.

SCALISE, Sergio. Generative morphology. Dordrecht: Foris, 1984.

VILLALVA, Alina Maria Santos Mártires. Análise morfológica do português. Lisboa: Faculdade de Letras da Universidade de Coimbra, 1986 (Dissertação, Mestrado em Lingüística Portuguesa Descritiva). 